\title{
Fungsi Keluarga Terhadap Pengambilan Keputusan Remaja dalam Pemilihan Jurusan di Universitas
}

\author{
${ }^{1}$ Yeni Anna Appulembang, ${ }^{2}$ Agustina \\ ${ }^{1}$ Psikologi, Universitas Sriwijaya, Indonesia \\ ${ }^{2}$ Psikologi, Universitas Tarumanagara, Indonesia \\ Correspondence:email. ${ }^{1}$ yenianna@fk.unsri.ac.id
}

\begin{abstract}
Abstrak: Pada usia remaja, biasanya ditandai dengan perilaku yang seolah lepas dari peran orangtua dan lebih mandiri dalam melakukan keputusan sendiri. Namun pada usia remaja, keluarga memainkan peran dalam proses pengambilan keputusan salah satunya dalam pemilihan jurusan yang akan diambil oleh anak di Universitas. Tujuan penelitian ini adalah fungsi keluarga terhadap pengambilan keputusan dalam pemilihan jurusan di Universitas. Penelitian ini merupakan studi kausal kompartif. Jumlah subyek yang digunakan adalah 301 orang, dengan teknik pengambilan sampel nonprobability sampling. Alat ukur yang digunakan ada dua yaitu fungsi keluarga yang menggunakan Family Asessment Device $(F A D)$ dan alat ukur pengambilan keputusan menggunakan Career Decision-Making Profile. Berdasarkan hasil analisis data pada pengukuran fungsi keluarga, peneliti menemukan nilai mean empiric lebih kecil dari mean hipotetik. Artinya fungsi keluarga dalam penelitian ini tergolong rendah. Berdasarkan hasil analisis dengan menggunakan simple regression, menunjukkan nilai $\mathrm{F}$ hitung sebesar 0,790 dengan nilai $p$ sebesar 0.099 $>0.05$ bahwa tidak terdapat peranan fungsi keluarga terhadap pengambilan keputusan dalam pemilihan jurusan di Universitas.
\end{abstract}

Kata kunci: Pengambilan Keputusan, Fungsi Keluarga, Remaja

\begin{abstract}
Adolescence is a period where their seems to be separated from the role of their parents and more independent in making their own decisions. But this time, the family plays a role in the behavior of adolescents in the decision making process, one of which is related to education in the selection of majors degree in university that will determine the future of their children. This research aims to determine the role of family support In adolescent for career decision making in major degree a in university. Causal comparative study was used and a sample 301 college student in grade one was selected through nonprobability sampling. This research was used two research tolls such as the role family was used Family Asessment Device (FAD) and decision making was used Career DecisionMaking Profile. The result in this research found that score of the role of family based on mean hipotetic is lower than mean empiric. It means that, the role of family low category. In this research also showed the result used simple regression, $F$ value 0.790 and $p$ value $0.099>0.05$. it means there is no significant the role of family support in adolescent for decision making in major degree in university.
\end{abstract}

Keyword: Decision making, Role of Family, Adolescent 


\section{PENDAHULUAN}

Masa remaja merupakan masa peralihan dari masa anak-anak menuju masa dewasa yang terjadi dalam rentang usia 12-20 tahun (Papalia $\&$ Martorell, 2012). Pada masa ini, remaja seolah lepas dari peran orangtua dan lebih mandiri dalam melakukan keputusan sendiri (Santrock, 2011). Namun menurut Hamdani ( 2014) keluarga memainkan peran terhadap perilaku remaja dalam mengambil keputusan di kehidupannya.

Keluarga merupakan suatu unit sosial penting dalam bangunan masyarakat. Keluarga dapat dibagi menjadi dua yaitu keluarga inti dan keluarga batih. Keluarga inti adalah keluarga yang didalamnya hanya terdapat tiga posisi sosial yaitu suami-ayah, istri-ibu dan anak sibling. Struktur keluarga yang demikian menjadikan keluarga sebagai orientasi bagi anak, yaitu keluarga tempat ia dilahirkan (Lestari, 2012).

Adapun fungsi keluarga terdiri atas 6 dimensi yaitu pemecahan masalah, komunikasi, peran, responsivitas afektif, keterlibatan afektif, kontrol perilaku. Dimensi pertama yaitu pemecahan masalah, dimensi ini merujuk kepada kemampuan keluarga untuk memecahkan masalah pada setiap level sehingga dapat menjaga fungsi keluarga tetap efektif. Dimensi kedua yaitu, komunikasi. Pada dimensi ini lebih berfokus kepada komunikasi secara verbal yang lebih dapat diukur. Dimensi ketiga yaitu peran. Pada dimensi ini terdapat peran dalam keluarga seperti peyediaan sumber daya ( penyediaan uang, makanan, pakaian dan tempat tinggal, adanya perawatan dan dukungan ( penyediaan kenyamanan, kehangatan, rasa aman dan dukungan untuk anggota anggota keluarga), adanya kepuasan seksual dewasa (pasangan suami istri secara personal merasakan kepuasan dalam hubungan seksual satu sama lain), adanya pengembangan pribadi (mendukung anggota keluarga dalam mengembangkan keterampilan ppribadi seperti perkembangan fisik, emosi, sosial dan pendidikan anak serta pengembangan karir dan perkemmbangan sosial dewasa), adanya pemeliharaan dan pengelolaan sistem keluarga (melibatkan teknik tindakan yang dibutuhkan untuk mempertahankan standar keluarga seperti pengambilan keputusan, batasan dan fungsi keanggotaan dalam keluarga, implementasi dan kontrol perilaku, pengaturan keuangan rumah tangga dan hal yang berkaitan dengan pengasuhan dan kesehatan keluarga). Dimensi keempat yaitu responsivitas afektif, yaitu kemampuan berespon terhadap stimulus yang ada dengan kualitas dan kuantitas perasaan yang tepat. Dimensi kelima yaitu keterlibatan afektif merupakan sejauh mana anggota keluarga menunjukkan ketertarikan dan penghargaan kepada aktivitas dan minat anggota keluarga lainnya. Dimensi keenam yaitu kontrol perilaku, mengenai pola yang diadopsi oleh keluarga untuk menangani perilaku anggota keluarga dalam tiga area yaitu situasi yang membahayakan secara fisik, situasi yang melibatkan pemenuhan kebutuhan dan dorongan psikologis, situasi yang melibatkan perilaku sosialiasi interpersonal baik diantara anggota keluarga maupun dengan oranglain di luar keluarga ( Epstein et all, 2003 dalam Pratiwi, A.B.R, 2014).

Menurut Miski dan Mawarpury, (2017) keluarga yang pada umumnya adalah orangtua ikut terlibat dalam proses pengambilan keputusan remaja salah satunya dalam hal pendidikan.

Mahasiswa dalam memilih jurusan biasanya bukan karena faktor internal tetapi mengikuti keinginan orangtua mengingat biaya pendidikan tidak terlepas dari tanggungan orangtua (Sulistyawati, Herawati \& Julianto, 2017). Rini (2014) menambahkan bahwa, pada proses pengambilan keputusan remaja dalam hal pendidikan, biasanya orangtua ikut terlibat. Posisi orangtua yang strategis dalam keluarga dan adanya kontrol, menuntut keterlibatan orangtua dalam proses pengambilan keputusan pendidikan khususnya pemilihan jurusan yang akan menentukan masa depan anaknya

Pengambilan keputusan adalah menilai dan membuat pilihan diantara pilihan-pilihan yang berbeda-beda (McBride \& Cutting, 2016).

Model umum dalam pengambilan keputusan berdasarkan 5 (lima) tahap yaitu: (1) Menentukan tujuan. Tujuan adalah representasi mental dari keadaan yang diinginkan. Keputusan yang baik adalah keputusan yang dapat membawa individu lebih dekat ke tujuannya; (2) Mengumpulkan informasi. Setelah individu telah menentukan tujuan, kemudian mengumpulkan informasi yang dibutuhkan untuk membuat keputusan. Informasi ini meliputi pilihan-pilihan, kemungkinan dari hasil yang berbeda, dan kriteria yang digunakan untuk membuat keputusan; (3) Menstruktur keputusan. Setelah individu memiliki tujuan dan mengumpulkan informasi, kemudian menyusun informasi yang berguna untuk membuat keputusan. Cara yang paling umum adalah dengan membuat daftar pro dan kontra; (4) Membuat keputusan final. Setelah 
mengumpulkan informasi dan menyusunnya kemudian dibandingkan, kemudian memilih. Ini bukanlah hal yang mudah untuk dilakukan. Seringkali tidak ada pilihan yang jelas. Ketika individu membuat keputusan, individu biasanya menyeleksi berdasarkan informasi yang tidak meyakinkan. (5) Evaluasi. Ini merupakan tahap terakhir yang sering terabaikan. Pada bagian ini, individu akan mengevaluasi apakah pilihan tesebut benar atau tidak. Bagian ini merupakan aspek terpenting dari pengambilan keputusan Galotti (dalam McBride \& Cutting, 2016.

Berdasarkan hasil penelitian yang dilakukan Whiston dan Keller (Children, Eer, \& Clutter, 2010) menemukan bahwa terdapat $20 \%$ pengaruh fungsi keluarga terhadap pengembangan karir dan pemilihan jurusan.

Selain itu penelitian yang dilakukan oleh Arfianto (2013) menunjukkan bahwa terdapat hubungan yang sangat signifikan antara interaksi keluarga dan peran orangtua terhadap keputusan dalam pemilihan jurusan. Pada penelitian ini menunjukkan bahwa terdapat koefisien determinan interaksi keluarga dan peran orangtua terhadap keputusan dalam pemilihan jurusan sebesar 31,2\%. Hal ini menunjukkan jika interaksi keluarga dan peran orang tua berjalan dengan baik maka keputusan pemilihan jurusan juga akan baik, tetapi sebaliknya jika interaksi keluarga dan peran orang tua buruk maka keputusan pemilihan jurusan juga akan buruk hasilnya.

Penelitian yang dilakukan oleh (Rini, 2014) dengan melakukan in depth interview kepada responden dan menunjukkan bahwa terdapat interaksi komunikasi antara anak dan orangtua dalam proses pengambilan keputusan dalam memilih jurusan. Orangtua memberikan kesempatan dan kebebasan berpendapat yang dibutuhkan oleh anak dalam pengambilan keputusan. Selain itu, orangtua juga memberikan kesempatan dan kebebasan kepada anak untuk menyampaikan pilihan jurusan yang diinginkannya dan menjelaskan alasan pilihannya tersebut.

Oleh karena itu, Pengambilan keputusan dalam menentukan jurusan apa yang akan diambil bukanlah hal mudah. Pengambilan keputusan yang rendah dan lebih banyak dipengaruhi orang lain mengakibatkan proses belajar siswa dan hasil prestasi siswa menjadi terhambat karena adanya ketidaksesuaian dalam diri individu. Dengan demikian tujuan penelitian ini adalah untuk mengetahui peranan fungsi keluarga terhadap pengambilan keputusan pada pemilihan jurusan di universitas. Adapun hipotesis penelitian ini terdapat peranan fungsi keluarga terhadap pengambilan keputusan dalam pemilihan jurusan di Universitas.

\section{METODE}

Penelitian ini merupakan studi kausal kompartif. Tujuan Penelitian ini melakukan pengujian mengenai fungsi keluarga terhadap pengambilan keputusan dalam pemilihan jurusan di Universitas. Subyek yang digunakan adalah remaja akhir yang sedang menempuh pendidikan di universitas pada semester pertama. Jumlah subyek yang digunakan adalah 301 orang, subyek dipilih dengan menggunakan teknik pengambilan sampel nonprobability sampling. Penelitian ini juga telah melalui proses monitoring dan evaluasi dari Universitas Tarumanagara.

Pada penelitian ini, alat ukur yang digunakan ada dua yaitu fungsi keluarga dan pengambilan keputusan. Pada alat ukur fungsi keluarga menggunakan Family Asessment Device ( $F A D$, yang dikembangkan oleh Epstein et al. (1983 dalam Pratiwi, 2014). Alat ukur ini terdiri atas enam (6) dimensi yaitu pemecahan masalah, komunikasi, peran, responsivitas afektif, keterlibatan afektif, dan kontrol perilaku. Alat ukur pada fungsi keluarga memiliki 27 butir pernyataan dengan skala Likert yang dibagi menjadi empat (4) pilihan yaitu $1=($ STS $)$ Sangat Tidak Setuju, $2=($ TS) Tidak Setuju, $3=(\mathrm{S})$ Setuju, dan $4=($ SS) Sangat Setuju. Alat ukur kedua adalah pengambilan keputusan. pada alat ukur kedua ini, peneliti menggunakan Career Decision-Making Profile yang dikembangkan oleh Gati, Landman, Davidovitch, Asulin-Peretz, dan Gadassi (1987).

Alat ukur pengambilan keputusan terdiri atas lima (5) tahap yaitu menentukan tujuan, mengumpulkan informasi, menstruktur keputusan, membuat keputusan final dan evaluasi. Alat ukur ini diadaptasi oleh Agustina dan Monty (2017) yang terdiri atas 18 butir pernyataan dengan menggunakan skala Likert yang dibagi menjadi lima (5) pilihan yaitu $1=$ (STS) Sangat Tidak Setuju, $2=$ (TS) Tidak Setuju, $3=(\mathrm{RR})$ Ragu-ragu, $4=(\mathrm{S})$ Setuju dan $5=($ SS) Sangat Setuju. Butir-butir pada alat ukur ini dianalis dengan menggunakan Simple Regression.

\section{HASIL DAN PEMBAHASAN}

Berdasarkan hasil analisis data pada pengukuran fungsi keluarga dan menemukan 


\section{1 | JURKAM: Jurnal Konseling Andi Matappa Vol 4, No 1, Februari 2020}

nilai mean hipotetik sebesar 2,50 dan mean empiric sebesar 1,98. Hal ini menunjukkan bahwa nilai mean empiric lebih kecil dari mean hipotetik $(1,98>2,50)$. Artinya fungsi keluarga dalam penelitian ini tergolong rendah.

Peneliti juga melakukan uji One Sample Kolmogorov-Smirnov, pada variabel fungsi keluarga dan pengambilan keputusan. Pada variabel fungsi keluarga diperoleh nilai $p$ sebesar 0.055 yang lebih besar dari $0.05(0.055>0.05)$, artinya variabel fungsi keluarga berada pada distribusi normal (paramterik). Pada variabel pengambilan keputusan menunjukkan nilai $p$ sebesar 0.150 yang lebih besar dari 0.05 $(0.150>0.05)$. Hal ini menunjukkan bahwa variabel pengambilan keputusan berada pada distribusi normal(paramterik). Untuk lebih detail dapat dilihat pada tabel 1 berikut:

Tabel.1. Hasil Uji Normalitas Fungsi Keluarga dan Pengambilan Keputusan

\begin{tabular}{lcc}
\hline Variabel & $\mathrm{Z}$ & $P$ \\
\hline Fungsi Keluarga & 1.340 & 0.055 \\
Pengambilan Keputusan & 1.137 & 0.150 \\
\hline
\end{tabular}

Berdasarkan hasil analisis data, maka diperoleh nilai $\mathrm{R}$ sebesar 0,095. Hal ini menunjukkan bahwa sumbangan fungsi keluarga pada pengambilan keputusan dalam memilih jurusan di Universitas sebesar 9,5\% dan sisanya dipengaruhi oleh faktor-faktor lain yang tidak diteliti dalam penelitian ini. Untuk detail dapat dilihat pada tabel 2 dibawah ini

Tabel 2. Hasil Uji Regresi Fungsi Keluarga terhadap Pengambilan Keputusan

\begin{tabular}{|c|c|c|c|}
\hline $\mathrm{R}$ & R Square & Adjusted R Square & Std. Error of the Estimate \\
\hline, $095^{\mathrm{a}}$ & ,009 & ,006 & ,53731 \\
\hline
\end{tabular}

Tabel 3. Hasil Uji Regresi Fungsi Keluarga terhadap Pengambilan Keputusan

\begin{tabular}{lrrr}
\hline \multicolumn{1}{c}{ Model } & Sum of Squares & df & \multicolumn{2}{c}{ Mean Square } \\
\hline Regression &, 790 & 1 &, 790 \\
Residual & 86,322 & 299 &, 289 \\
Total & 87,112 & 300 & \\
\hline
\end{tabular}

Berdasarkan hasil analisis dengan menggunakan simple regression, menunjukkan nilai $\mathrm{F}$ hitung sebesar 0,790 dengan nilai $p$ sebesar $0.099>0.05$ bahwa tidak terdapat peranan fungsi keluarga terhadap pengambilan keputusan dalam pemilihan jurusan di Universitas. Hasil penelitian yang telah ditemukan oleh peneliti, analisis data, didukung oleh pernyataan Papalia dan Martorell (2012), pada masa ini para remaja justru menghabiskan lebih banyak waktu dengan teman sebaya mereka dan lebih sedikit waktu dengan keluarganya. Pada masa ini, fungsi keluarga tidaklah dominan dalam pengambilan keputusan remaja. Selain itu, Miski dan Mawarpury (2017) juga mengatakan bahwa tidak dapat dipungkiri bahwa teman sebaya dan lingkungan sekitar juga dapat terlibat dalam penentuan keputusan remaja dalam memilih jurusan pendidikan.

Namun hasil penelitian ini tidak sesuai dengan hasil penelitian yang dilakukan oleh (Rani, 2014) yang menunjukkan bahwa terdapat 
peranan keluarga dalam pengembangan karir. Pada penelitian ini juga menemukan bahwa dukungan keluarga mempengaruhi keputusan dalam pemilihan jurusan.

Penelitian ini didukung oleh peneliltian yang dilakukan oleh (Sitepu, 2014) menunjukkan bahwa pengambilan keputusan dalam keluarga didominasi oleh orangtua khususnya hal-hal yang berkaitan langsung dengan anak seperti pendidikan. Meskipun orangtua sudah mulai terbuka dan mau melibatkan anak dalam pengambilan keputusan. Sama seperti penelitian yang dilakukan oleh Arfianto (2013) menunjukkan bahwa terdapat hubungan yang sangat signifikan antara interaksi keluarga dan peran orangtua terhadap keputusan dalam pemilihan jurusan. Pada penelitian ini menunjukkan bahwa terdapat koefisien determinan interaksi keluarga dan peran orangtua terhadap keputusan dalam pemilihan jurusan sebesar 31,2\%. Hal ini menunjukkan jika interaksi keluarga dan peran orang tua berjalan dengan baik maka keputusan pemilihan jurusan juga akan baik, tetapi sebaliknya jika interaksi keluarga dan peran orang tua buruk maka keputusan pemilihan jurusan juga akan buruk hasilnya.

Penelitian ini didukung oleh hasil survey penelitian dari beberapa kota di Indonesia oleh BAK (Badan Administrasi Kemahasiswaan) di Universitas $X$ di Madiun (Laksmawati, Psikologi, Katolik, \& Mandala, 2014) dan menunjukkan hasil bahwa pengambilan keputusan yang berasal dari diri sendiri yang menduduki nilai rating tertinggi dari enam faktor. Orangtua menduduki peringkat kedua dalam nilai rating tertingginya. Pada tahun 2011 peringkat pengambilan keputusan yang dipengaruhi oleh diri sendiri adalah $37,43 \%$ sedangkan pengambilan keputusan yang dipengaruhi peran orangtua adalah $35,89 \%$ dari jumlah mahasiswa sebanyak 202 orang. Kemudian pada tahun 2012 peringkat pengambilan keputusan yang dipengaruhi oleh diri sendiri adalah 33,73\% sedangkan pengambilan keputusan yang dipengaruhi peran orangtua adalah 32,93\% dari jumlah mahasiswa sebanyak 183 orang. Selain itu, penelitian yang dilakukan (Hastuti \& Prabowo, 2011) juga menemukan bahwa lingkungan eksternal (keluarga dan teman) tidak dan peran/status tidak memilihi pengaruh yang signifikan terhadap pengambilan keputusan dalam pemilihan jurusan di Universitas $\mathrm{X}$ Cimahi.
Penelitian ini tidak didukung oleh penelitian yang dilakukan oleh Istifarani, F (2016) menemukan bahwa tidak terdapat pengaruh yang signifikan antara dukungan keluarga terhadap pengambilan keputusan karir siswa. Tidak adanya pengaruh antara dukungan keluarga dengan pengambilan keputusan dalam karir disebabkan karena beberapa faktor pada diri siswa seperti semakin mandirinya siswa dalam menentukan piihan karirinya sendiri tanpa memperdulikan pendapat orangtua maupun anggota keluarga lainnya.

Penelitian ini juga tidak didukung oleh hasil penelitian yang dilakukan oleh (Sulistyawati, Herawati \& Julianto, 2017) dengan menggunakan hasil uji $t$ secara parsial menunjukkan nilai signifikansi variabel dukungan orangtua sebesar 0,000 . Hal tersebut menunjukkan bahwa variabel dukungan orangtua berpengaruh positif terhadap keputusan memilih jurusan akuntansi. Penelitian ini tidak didukung oleh hasil penelitian yang dilakukan oleh (Nurwakhidah, 2014) juga menemukan bahwa $p$ sebesar $0,641<0.05$ artinya faktor orangtua tidak memiliki pengaruh yang signifikan terhadap pengambilan keputusan mahasiswa dalam memilih jurusan IPS di Universitas X. Selain itu penelitian yang dilakukan oleh (Rumono, Setyabudi \& Pradekso, 2014) mengenai hubungan intensitas komunikasi orang tua - anak (X1) dengan minat memilih jurusan Ilmu Komunikasi (Y) dan diperoleh nilai $p$ sebesar $0,154<0.05$, artinya tidak ada hubungan yang signifikan antara intensitas komunikasi orangtuaanak dengan minat memilih jurusan ilmu komunikasi. Hal ini diartikan bahwa tinggi rendahnya intensitas komunikasi orangtua-anak tidak memiliki hubungan dengan minat siswa untuk memilih jurusan. Hal ini disebabkan karena proses komunikasi pada setiap keluarga memiliki pola komunikasi yang berbeda. Pola komunikasi tersebut dapat dicermati melalui tipetipe keluarga. Tipe keluarga ini juga akan menjelaskan kebebasan anggota keluarga dalam berkomunikasi dan pengambilan keputusan

\section{SIMPULAN DAN SARAN}

Berdasarkan hasil analisis data pada pengukuran fungsi keluarga dan menemukan nilai mean empiric lebih kecil dari mean hipotetik. Artinya fungsi keluarga dalam penelitian ini tergolong rendah. Pada penelitian ini, peneliti juga menemukan, nilai $\mathrm{R}$ sebesar 0,095 . Hal ini menunjukkan bahwa sumbangan 
fungsi keluarga pada pengambilan keputusan dalam memilih jurusan di Universitas sebesar 9,5\% dan sisanya dipengaruhi oleh faktor-faktor lain yang tidak diteliti dalam penelitian ini. Berdasarkan hasil analisis dengan menggunakan simple regression, menunjukkan bahwa tidak terdapat peranan fungsi keluarga terhadap pengambilan keputusan dalam pemilihan jurusan di Universitas.

\section{DAFTAR RUJUKAN}

Agustina \& Satiadarma, M. P. (2017). Peranan status identitas terhadap pengambilan keputusan pemilihan jurusan di universitas pada mahasiswa tingkat awal. Jakarta: Direktorat Penelitian dan Pengabdian Kepada Masyarakat.

Arfianto, I (2013). Interaksi Keluarga Dan Peran Orang Tua Terhadap Keputusan Pemilihan Jurusan Pada Siswa SMA Di Palembang. Seminar Nasional Keberbakatan Optimalisasi Potensi Siswa Gifted, 18 Mei 2013. Universitas Muhammadiyah Malang.

Clutter, C (2010). The Effect of Parental Influence On Their Children's Career Choices. School of Family Studies and Human Service College of Human Ecology. (Theses: Kansas State University Manhattan, Kansas).

Hamdani, S. (2014). Pengaruh keberfungsian keluarga terhadap prestasi belajar siswa pada mata pelajaran sosiologi. .upi.edu |perpustakaan.upi.edu. Diakses tanggal 5 April 2018.

Hastuti, S \& Prabowo, H.R.M.J (2011). Analisis Faktor-Faktor Yang Mempengaruhi Pengambilan Keputusan Mmahasiswa Baru Program S1 Dalam Memilih Jurusan Pada Universitas Jenderal Achmad Yani Cimahi. Portofolio Vol. 8 No. 1.

Istifarani, F ( 2016). Pengaruh Dukungan Keluarga Terhadap Pengambilan Keputusan Karir Siswa Kelas X Di SMK Negeri 1 Depok. Jurnal Bimbingan dan Konseling, edisi 4
Laksmawati, V, E ( 2014). Pengambilan Keputusan Memilih Program Studi Ditinjau Dari Persepsi Terhadap Peran Orangtua Dan Pilihan Pribadi Mahasiswa Universitas Katolik Widya Mandala Madiun. (Skripsi: Universitas Katolik Widya Mandala Madiun).

Lestari, S (2012) Psikologi Keluarga: Penanaman Nilai dan Penanganan Konflik dalam Keluarga. Jakarta: Kencana.

McBride, D. M. \& Cutting, J. C. (2015). Cognitrive psychology: Theory, process, and methodology. NY: Sage Publications

Miski, R. \& Mawarpury, M. (2017). Pengambilan keputusan pada remaja yang mengalami pengasuhan otoriter. Jurnal Ecopsy. 1 (3), 157-162.

Nurwakhidah (2014). Analisis Faktor-faktor Yang Mempengaruhi Keputusan Mahasiswa Dalam Memilih Jurusan Pendidikan IPS Fakultas Ilmu Tarbiyah dan Keguruan UIN Syarif Hidayatullah Jakarta. (Skripsi: UIN Syarif Hidayatullah Jakarta).

Papalia, D. E., \& Martorell, G. (2012). Experience human development $\left(12^{\mathrm{nd}}\right.$ ed.). NY: McGraw-Hill.

Pratiwi, A.B.R (2014). Hubungan Fungsi Keluarga Terhadap Tingkat Kecerdasan Emosional Para Pelajar Di SMP Jaya Suti Abadi Kabupaten Bekasi. Program Studi Ilmu Keperawatan Fakultas Kedokteran Dan Ilmu Kesehatan UIN Syarif Hidayatullah Jakarta.

Rini, Y, S ( 2014). Komunikasi Orangtua-Anak dalam Pengambilan Keputusan Pendidikan. Jurnal Interaksi, Vol 3 (2), 2014 112-122 Rumono, H, N., Setyabudi, D \& Pradekso, T ( 2014). Hubungan Intensitas Komunikasi Orangtua-Anak dan Kelompok Referensi Dengan Minat Memilih Jurusan Ilmu Komunikasi Pada Siswa Kelas XII. Jurnal Ilmu Komunikasi, Fisip UNDIP .

Santrock, J. W. (2011). Adolescence. Boston, USA: McGraw Hill. 
Sitepu, A, L (2014). Keterlibatan Anak Remaja Dalam Pengambilan Keputusan Mengenai Keputusannya Serta Kaitannya Dengan Gaya Pengasuhan Orangtua. Program Studi Sosiologi, Fakultas Ilmu Sosial dan Ilmu Politik, Universitas Indonesia.

Sulistyawati, N.L.G.A., Herawati. N. T., \& Julianto. P ( 2017). Pengaruh Minat, Potensi Diri, Dukungan Orang Tua, Dan Kesempatan Kerja Terhadap Keputusan Mahasiswa Memilih Jurusan Akuntansi Program S1 Universitas Pendidikan Ganesha. Ejournal SIAK Universitas Pendidikan Ganesha, Jurusan Akuntansi Program S1, Vol 8 